\title{
Coronavirus Effects on the Economy of Jordan
}

\author{
Khaled Abdalla Moh'd AL-Tamimi ${ }^{1}$ \\ ${ }^{1}$ Department of Financial and Administrative Sciences, Irbid University College, Al-Balqa' Applied University, \\ Jordan \\ Correspondence: Dr. Khaled Abdalla Moh'd AL-Tamimi, Associate professor, Department of Financial and \\ Administrative Sciences, Irbid University College, Al-Balqa' Applied University, Jordan.
}

Received: June 26, 2020

doi:10.5430/ijfr.v11n5p129
Accepted: September 6, 2020

URL: https://doi.org/10.5430/ijfr.v11n5p129

\begin{abstract}
This paper reports the effects of coronavirus on Jordan's economic growth by using quarterly data for the period (2018/2019 Q1 - 2019/2020 Q4), where the numbers of people who are sick with coronavirus and those that have died from the virus are explanatory variables, and economic growth is an affected variable. The research concentrates on analyzing reviews of theoretical and empirical literature to show the effect of coronavirus on economic growth and explaining this effect in Jordan in this period by using the ARDL technique in Eviews. By using quarterly data for $(2018 / 2019$ Q1 - 2019/2020 Q4) at a significance level of 5\%, this research demonstrates that the numbers of people who are ill with coronavirus and those that have died from the virus have a weak positive effect and a negative but significant effect on the economic growth of Jordan, respectively. The research also shows a recommendation of limiting the negative effects of coronavirus by reducing the number of deaths via strengthening the health service and opening some economic sectors to boost economic growth in the country.
\end{abstract}

Keywords: coronavirus, economic growth, Jordan economy, ARDL method

\section{Introduction}

Coronavirus first appeared in Wuhan city, China on 31 December 2019. Coronavirus belongs to an enormous infectious group of viruses. The World Health Organization works with a huge group of governments, specialists, and other organizations to give advice and guidance to countries about preventive measures of the coronavirus disease (Abinraj, 2020, p. 1).

As of 16 March 2020, there were about 167,511 confirmed persons who were ill with coronavirus and 6,606 persons who have died from the virus in the world. Now, the numbers of those cases have increased (Haruna, 2020, p. 1) and (Fernandes, 2020, p. 2). Coronavirus is a pandemic that has a lot of effects. There are political and economic impacts of coronavirus. A lot of channels such as trade, investment, and a decline in oil prices can transfer the effect of coronavirus on the economies of countries (Haruna, 2020, pp. 1 - 2) and (OECD, 2020, p. 1). So, The research estimates coronavirus impact on Jordan's economic growth by using quarterly data for (2018/2019 Q1 - 2019/2020 Q4), by showing literature review on coronavirus impact on economic growth and estimating the impact of the virus on Jordan's economic growth using the ARDL technique in Eviews.

\section{Research Questions}

The basic question of the research is: what is the effect of coronavirus on Jordan's economic growth by using quarterly data for (2018/2019 Q1 - 2019/2020 Q4)?

Other questions arise from the basic question like:

1. What are the literature reviews that explain the effect of coronavirus on economic growth?

2. What are the slopes of the curves the numbers of people who are ill with coronavirus and those that have died from the virus in Jordan by using quarterly data for (2018/2019 Q1 - 2019/2020 Q4)?

3. What is the slope of the curve of Jordan's economic growth by using quarterly data for (2018/2019 Q1 2019/2020 Q4)?

\section{Research Aims}

The basic aim of the research is to test the impact of coronavirus on Jordan's economic growth by using quarterly 
data for (2018/2019 Q1 - 2019/2020 Q4).

The following are other aims that may arise:

1. Explaining theoretical and empirical literature reviews that explore the effect of coronavirus on economic growth.

2. Knowing the slopes of the curves of Jordan's numbers of people who are ill with coronavirus and those that have died from the virus by using quarterly data for (2018/2019 Q1 - 2019/2020 Q4).

3. Determining the slope of the curve of Jordan's economic growth by using quarterly data for (2018/2019 Q1 - 2019/2020 Q4).

\section{Research Hypothesis}

The basic hypothesis of the research is there is a depressing impact of coronavirus on Jordan's economic growth by using quarterly data for $(2018 / 2019$ Q1 - 2019/2020 Q4).

\section{Literature Review}

Coronavirus impact on economic growth can be shown by the following impacts:

- Vehicles Industry: as a result of coronavirus, the vehicles industry of any economy can be affected in the form of a constrain but the effect differs from one country to another.

- Pharmaceutical Industry: since the pharmaceutical industry depends heavily on the importation of medications, the effect of coronavirus on this industry may come due to restriction in the movement of people, goods, etc.

- Materials Sector: because of coronavirus spread, many plants used in the manufacturing of materials like textile fabrics and crude materials have been closed thus affecting the availability of these materials.

- Sector of sun oriented power: some countries may have a problem of a deficit in required crude materials in cells that are concerned with sun oriented power.

- IT Industry: coronavirus has affected the IT industry badly as it has lowered the development and income of IT organizations.

- Hardware Industry: as a result of coronavirus spread, the electronic industry has been affected as there are supply interruptions and a decrease in costs of items.

- Travel and Aviation Industry: coronavirus has affected the industry of travel and aviation badly as there is a drastic decrease in the number of vacationers from one country to another and thus affecting the segment and the income it generates in all countries affected by coronavirus spread (Abinraj, 2020, pg. 2 - 3) and (Mahmud, 2020, pp. 1 - 2).

The researcher can show a depressing impact of coronavirus because the increasing numbers of people who are ill with the virus and those who have died from it lower Jordan's economic growth (Keelery, 2020, p. 3) and (Ayittey, F. \& et al, 2020, p. 1).

Coronavirus impact on Jordan's economy can be shown by the following studies:

Jordan is one of the countries that succeeded in a Covid-19 curve flattening, as Jordan recorded the first case on 2 March 2020 but till now, it has a flattening curve of Covid-19 in the context of its population of 10.2 million. Jordan has a rank of $160^{\text {th }}$ out of 215 states that have recorded cases. Its rank is 154 for coronavirus deaths. It is one of the countries with the highest number of tests which puts it in the top third of all countries around the world (Zaineldine, 2020). Although there is an improvement in response to coronavirus in Jordan, a lot of sectors in the country have been affected like the industry of services which is the largest sector in the economy of Jordan. The country did a lot of efforts to lower its programs of welfare from the 2000s by removing food, oil, and water subsidies, but this process may have an effect on more protests and create another challenge in Jordan. Another problem that Jordan faces is foreign aid loss (Zaineldine, 2020).

\section{Coronavirus Impact on Jordan's Economic Growth by Using Quarterly Data for (2018/2019 Q1 - 2019/2020 Q4)}

\subsection{Method}

The research uses quarterly data for (2018/2019 Q1 - 2019/2020 Q4) for Jordan's number of people who are ill with coronavirus, the number of people who have died from the virus and economic growth. Coronavirus effect on 
Jordan's economic growth can be determined by the following equation:

Economic growt $h_{t}=f$ (number of people who are ill with coronavirus ${ }_{\mathrm{t}}$, number of people who are dead with coronavirus $\mathrm{t}_{\mathrm{t}}$ )

\subsection{Results}

This part explains Jordan's number of people who are ill with coronavirus, number of people who have died from the virus and economic growth by using quarterly data for (2018/2019 Q1 - 2019/2020 Q4) as follows:

6.2.1 Jordan's Number of People Who Are Ill With Coronavirus

Table 1. Jordan's number of people who are ill with coronavirus by using quarterly data for (2018/2019 Q1 2019/2020 Q4)

\begin{tabular}{cc}
\hline Year & $\begin{array}{c}\text { Jordan's number of people who are ill } \\
\text { with coronavirus }\end{array}$ \\
\hline 2018/2019Q1 & 0 \\
2018/2019Q2 & 0 \\
2018/2019Q3 & 0 \\
2018/2019Q4 $019 / 2020 Q 1$ & 0 \\
2019/2020Q2 & 0 \\
$2019 / 2020 Q 3$ & 0 \\
$2019 / 2020 Q 4$ & 6 \\
\hline
\end{tabular}

Source: designed by a researcher by using Trading Economics Data

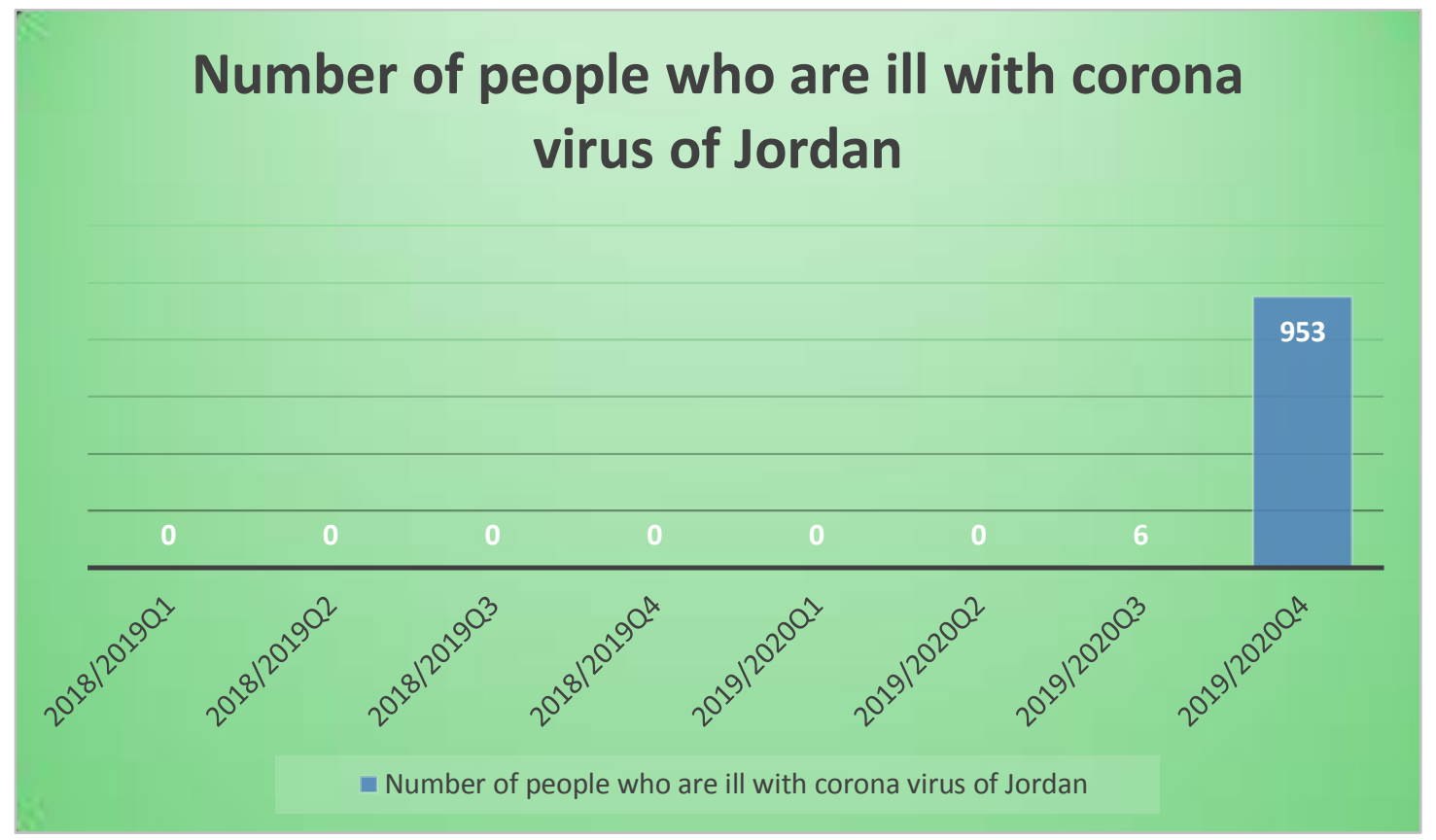

Figure 1. Jordan's number of people who are ill with coronavirus by using quarterly data for (2018/2019 Q1 2019/2020 Q4)

Source: designed by a researcher by using Trading Economics Data 
Table 1 and Figure 1 show that no one who is ill with coronavirus exists in the country by using quarterly data for (2018/2019 Q1 - 2019/2020 Q2). At the end of 2019/2020 Q3, there are 6 people who are ill with coronavirus. Then the number of people who are ill with coronavirus increases to 953 at the end of 2019/2020 Q4.

\subsubsection{Jordan's Number of People Who Have Died From Coronavirus}

Table 2. Jordan's number of people who have died from coronavirus by using quarterly data for (2018/2019 Q1 2019/2020 Q4)

\begin{tabular}{cc}
\hline Year & $\begin{array}{c}\text { Jordan's number of people who have } \\
\text { died from coronavirus }\end{array}$ \\
\hline 2018/2019Q1 & 0 \\
2018/2019Q2 & 0 \\
2018/2019Q3 $2018 / 2019 Q 4$ & 0 \\
2019/2020Q1 & 0 \\
2019/2020Q2 & 0 \\
2019/2020Q3 & 0 \\
2019/2020Q4 & 0 \\
\hline
\end{tabular}

Source: designed by a researcher by using Trading Economics Data

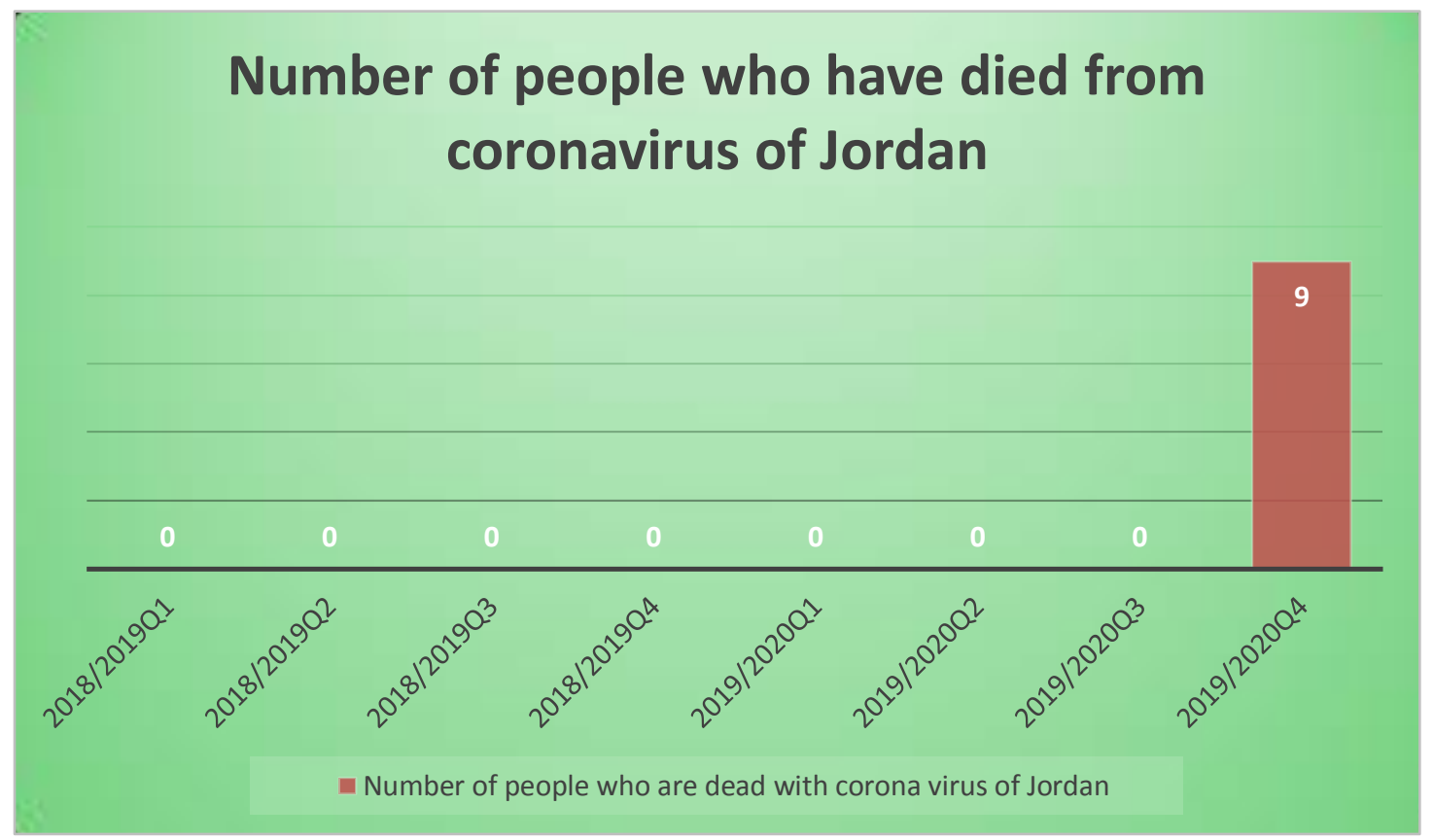

Figure 2. Jordan's number of people who have died from coronavirus by using quarterly data for (2018/2019 Q1 2019/2020 Q4)

Source: designed by a researcher by using Trading Economics Data

From Table 2 and Figure 2, no person was reported to have died from coronavirus in the country by using quarterly data for $(2018 / 2019$ Q1 - 2019/2020 Q3). At the end of 2019/2020 Q4, there are 9 people who have died from coronavirus. 


\subsubsection{Jordan's Economic Growth}

Table 3. Jordan's economic growth by using quarterly data for (2018/2019 Q1 - 2019/2020 Q4)

\begin{tabular}{cc}
\hline Year & $\begin{array}{c}\text { Jordan's economic } \\
\text { growth }\end{array}$ \\
\hline 2018/2019Q1 & 1.8 \\
2018/2019Q2 & 2 \\
2018/2019Q3 & 1.8 \\
2018/2019Q4 & 2 \\
2019/2020Q1 & 1.8 \\
2019/2020Q2 & 1.9 \\
2019/2020Q4 & 2.1 \\
\hline
\end{tabular}

Source: designed by a researcher by using Trading Economics Data

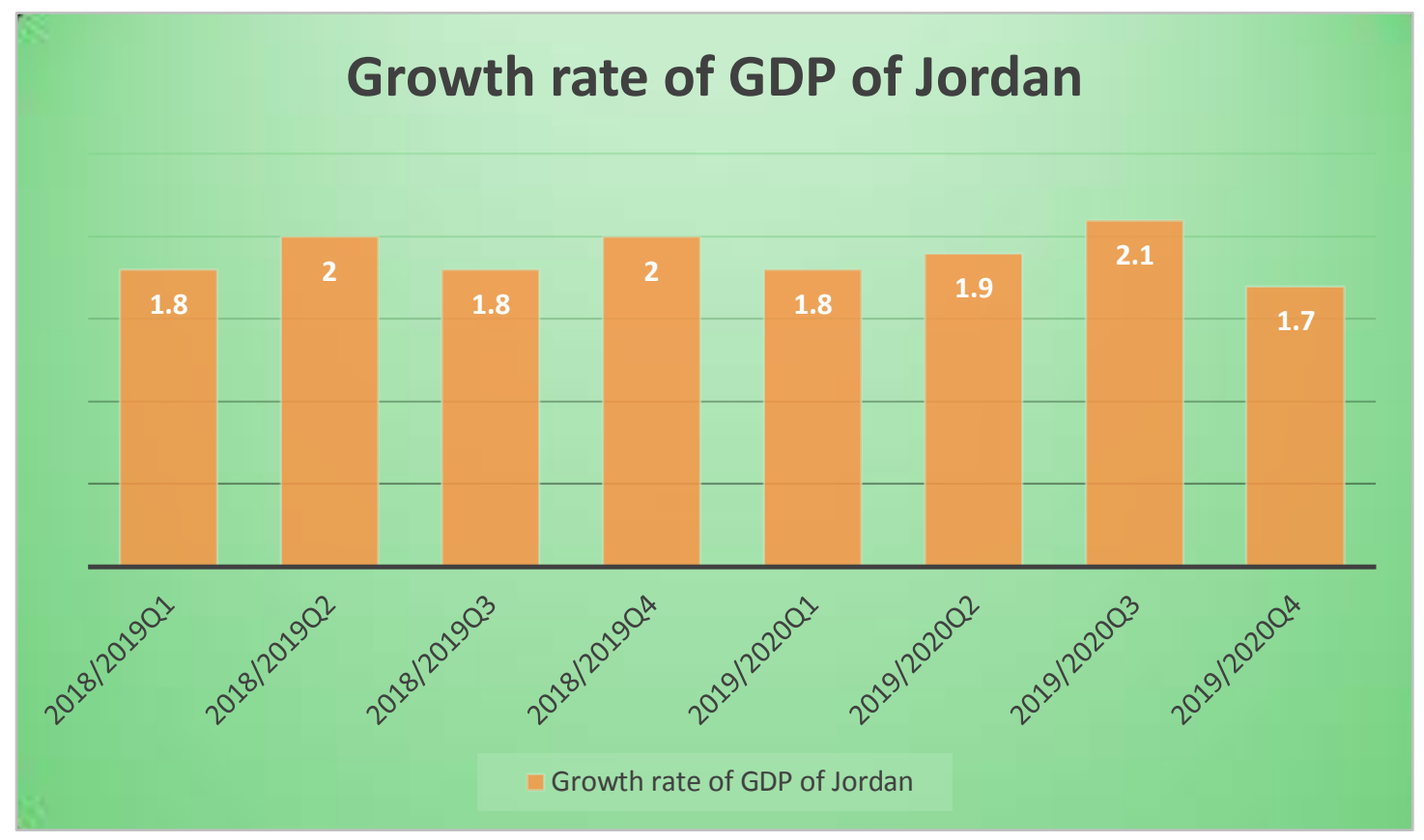

Figure 3. Jordan's economic growth by using quarterly data for (2018/2019 Q1 - 2019/2020 Q4)

Source: designed by a researcher by using Trading Economics Data

Table 3 and Figure 3 above show Jordan's economic growth by using quarterly data for (2018/2019 Q1 - 2019/2020 Q4). They indicate that there is a fluctuation in it during this duration between increases and decreases. In the end, it lowers to $1.7 \%$ in 2019/2020 Q4.

\section{Discussion}

The next table and figure show coronavirus effect on Jordan's economic growth by using quarterly data for (2018/2019 Q1 - 2019/2020 Q4) as follows: 
Table 4. Jordan's number of people who are ill with coronavirus, number of people who have died from coronavirus and economic growth by using quarterly data for (2018/2019 Q1 - 2019/2020 Q4)

\begin{tabular}{cccc}
\hline Year & $\begin{array}{c}\text { Jordan's number of } \\
\text { people who are ill with } \\
\text { corona virus }\end{array}$ & $\begin{array}{c}\text { Jordan's number of } \\
\text { people who have died } \\
\text { from coronavirus }\end{array}$ & $\begin{array}{c}\text { Jordan's economic } \\
\text { growth }\end{array}$ \\
\hline 2018/2019Q1 & 0 & 0 & 1.8 \\
2018/2019Q2 & 0 & 0 & 2 \\
2018/2019Q3 & 0 & 0 & 1.8 \\
2018/2019Q4 & 0 & 0 & 2 \\
2019/2020Q1 & 0 & 0 & 1.8 \\
2019/2020Q2 & 0 & 0 & 1.9 \\
2019/2020Q3 & 6 & 0 & 2.1 \\
2019/2020Q4 & 953 & 9 & 1.7 \\
\hline
\end{tabular}

Source: designed by a researcher by using Trading Economics Data

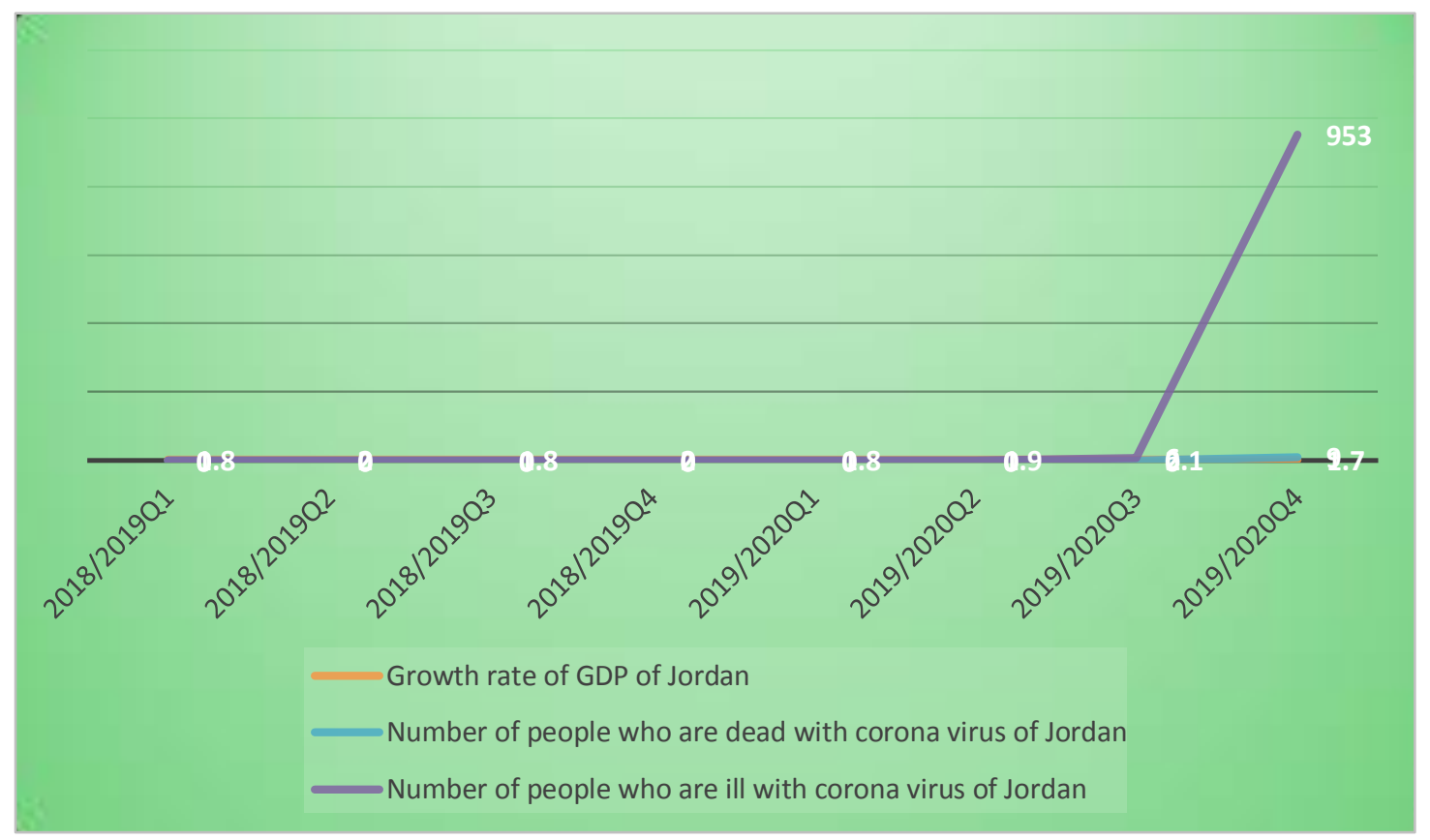

Figure 4. Jordan's number of people who are ill with coronavirus, number of people who have died from coronavirus and economic growth by using quarterly data for (2018/2019 Q1 - 2019/2020 Q4)

Source: designed by a researcher by using Trading Economics Data

Table 4 and Figure 4 refer to the impacts of people who are ill with coronavirus and the number of people who have died from coronavirus on Jordan's economic growth by using quarterly data for (2018/2019 Q1 - 2019/2020 Q4). The above table and chart refer to a negative effect of the number of people who are ill with coronavirus and the number of people who have died from the virus on Jordan's economic growth; because when the numbers of people who are ill with coronavirus and those who have died from the virus increase, the economic growth of the country lowers.

The research uses ARDL technique to test the effects of the number of people who are ill with coronavirus and number of people who have died from the virus on Jordan's economic growth by using quarterly data for (2018/2019 Q1 - 2019/2020 Q4) as follows: 
Dependent Variable: GR

Method: ARDL

Date: 06/26/20 Time: 12:51

Sample (adjusted): 2019Q2 2020Q4

Included observations: 7 after adjustments

Dependent lags: 1 (Fixed)

Dynamic regressors (0 lag, fixed): ILL DEAD

Fixed regressors: $\mathrm{C}$

\begin{tabular}{lllll}
\hline Prob.* & t-Statistic & Std. Error & Coefficient & Variable \\
\hline 0.0305 & -3.872983 & 0.215166 & -0.833333 & GR(-1) \\
0.0249 & 4.181239 & 0.008636 & 0.036111 & ILL \\
0.0248 & -4.189483 & 0.913148 & -3.825617 & DEAD \\
0.0034 & 8.558391 & 0.405061 & 3.466667 & C \\
\hline \multirow{2}{*}{1.900000} & Mean dependent var & 0.944444 & R-squared \\
0.141421 & S.D. dependent var & 0.888889 & Adjusted R-squared \\
-2.975811 & Akaike info criterion & 0.047140 & S.E. of regression \\
-3.006720 & Schwarz criterion & 0.006667 & Sum squared resid \\
-3.357834 & Hannan-Quinn criter. & 14.41534 & Log likelihood \\
1.833333 & Durbin-Watson stat & 17.00000 & F-statistic \\
& & 0.021856 & Prob(F-statistic) \\
\hline
\end{tabular}

The above table shows that there is a weak positive effect of the number of people who are ill with coronavirus on Jordan's economic growth but a negative and significant effect of the number of people who have died from the virus on Jordan's economic growth by using quarterly data for (2018/2019 Q1 - 2019/2020 Q4) at significance a level of $5 \%$.

\section{Conclusion and Recommendations}

The research estimates coronavirus effect on economic growth in literature reviews and the effects of the numbers of people who are ill with coronavirus and those who have died from the virus on Jordan's economic growth by using quarterly data for (2018/2019 Q1 - 2019/2020 Q4) by relying on the ARDL technique. This paper reaches a weak positive effect of the number of people who are ill with coronavirus on Jordan's economic growth but a negative and significant effect of the number of people who have died from the virus on Jordan's economic growth by using quarterly data for $(2018 / 2019$ Q1 - 2019/2020 Q4) at a significance level of 5\%. The research shows a recommendation limiting the negative effects of coronavirus by reducing the number of deaths via strengthening the health service and opening some economic sectors in order to boost economic growth in the country.

\section{References}

Abinraj, R. S. (2020, March). Impact of Corona Virus on Indian Economy \& Solutions to Tackle. K L University. Retrieved from https://www.researchgate.net/publication/340116322_Impact_of_Corona_Virus_on_Indian_Economy_Solutions _to_Tackle

Ayittey, F. et al.. (2020, February). Economic Impacts of Wuhan 2019-nVOC on China and the world. Journal of Medical Virology, 1-3. Retrieved from https://www.researchgate.net/publication/339209152_Economic_Impacts_of_Wuhan_2019-nCoV_on_China_a 
nd_the_World

Fernandes, N. (2020). Economic Effects of Coronavirus Outbreak (COVID-19) on the World Economy. IESE Business School, Spain, April, pp. 1-33. Retrieved from https://poseidon01.ssrn.com/delivery.php?ID=39603110209002609801707008609212208805803309500902609 410402511909808609411110507509702903109902805109605409012101802101012610611107300008502300 211912210711809511300607703703106707108502000309601209607800407009700710810002210407802711 9124116083101094\&EXT=pdf

Haruna, I. (2020). Economic Impact of Covid-19 on Ghana: What are the Channels?. University for Development Studies, Wa Campus, March, pp. 1-6. Retrieved from https://www.researchgate.net/publication/340117125_ECONOMIC_IMPACT_OF_COVID-19_ON_GHANA_ WHAT_ARE_THE_CHANNELS

Keelery, S. (2020). Impact of the Coronavirus on the Indian Economy - Statistics \& Facts, April. Retrieved from https://www.statista.com/topics/6304/covid-19-economic-impact-on-india/

Mahmud, S. (2020). Impact of Corona Virus on the Global Economy. Shahjalal University of Science and Technology, February, $\quad$ pp. 1-2. $\quad$ Retrieved from https://www.researchgate.net/publication/339435164_Impact_of_Corona_Virus_on_the_Global_Economy

OECD. (2020). The COVID-19 Crisis in Egypt, April, 1-5. Retrieved from https://www.oecd.org/mena/competitiveness/The-Covid-19-Crisis-in-Egypt.pdf

Zaineldine, A. (2020). The Case of Jordan: A COVID-19 Response from Next Door, Egyptian Streets, May. Retrieved from https://egyptianstreets.com/2020/05/21/the-case-of-jordan-a-covid-19-response-from-next-door/

\section{Copyrights}

Copyright for this article is retained by the author(s), with first publication rights granted to the journal.

This is an open-access article distributed under the terms and conditions of the Creative Commons Attribution license (http://creativecommons.org/licenses/by/4.0/). 